\title{
IMPLEMENTASI STEAM (SCIENCE, TECHNOLOGY, ENGINEERING, ARTS AND MATHEMATICS) DALAM PEMBELAJARAN ABAD 21
}

\author{
Iim Halimatul Mu'minah*1, Yeni suryaningsih ${ }^{2}$ \\ ${ }^{1,2,3}$ FKIP Pendidikan Biologi Universitas Majalengka; Jl. K.H Abdul halim No.103. \\ e-mail: *1iimhalimatul@unma.ac.id, 2yenialrasyid@gmail.com
}

\begin{abstract}
ABSTRAK
Dunia kerja abad 21 menghendaki pekerja memiliki penguasaan di bidang sains dan teknologi serta berbagai keterampilan berkomunikasi, berpikir kritis, kreativitas dan kemampuan kolaboratif. Pembelajaran IPA khususnya di Indonesia pada umumnya belum mengarahkan siswanya untuk menguasai keteramapilan tersebut. Untuk itu perlu dikembangkan pembelajaran yang mampu mengintegrasikan Science, Technology, Engineering, Arts and Mathematics melalui Implementasi STEAM dalam pembelajaran abad 21 ini. Pembelajaran STEAM mampu meningkatkan penguasaan akademis siswa juga mengimplementasikannya dalam kehidupan siswa sehari-hari sehingga diharapkan melalui pembelajaran STEAM ini mampu melatih keterampilan abad 21 pada siswa. Implementasi STEAM dalam Pembelajaran merupakan proses penerapan ide, gagasan, dan konsep yang terkandung dalam meta disiplin ilmu dalam sebuah pembelajaran yang diharapkan dapat meningkatkan kemampuan baik dalam aspek kognitif, afektif maupun psikomotorik peserta didik dalam menghadapi kemajuan Teknologi. Dalam penelitian ini dibahas bagaimana implementasi STEAM dalam pembelajaran Abad 21, khususnya pembelajaran IPA. Penelitian ini bertujuan untuk memberikan manfaat terkait STEAM (Science, Technologi, Engineering, Arts and Mathematics dan Imlementasinya dalam pembelajaran Abad 21 khususnya pembelajaran IPA di sekolah, baik guru, maupun dosen sebagai pelaku pembelajaran.
\end{abstract}

Kata Kunci : Implementasi, STEAM, Pembelajaraan Abad 21.

\begin{abstract}
The 21 st century world of work requires workers to have mastery in science and technology as well as a variety of communication skills, critical thinking, creativity and collaborative abilities. Science learning especially in Indonesia in general has not directed students to master these skills. For this reason, it is necessary to develop learning that is able to integrate Science, Technology, Engineering, Arts and Mathematics through STEAM Implementation in this 21 st century learning. STEAM learning is able to increase students 'academic mastery as well as implementing it in students' daily lives so it is hoped that through STEAM learning, students are able to practice 21st century skills. STEAM Implementation in Learning is the process of applying ideas, ideas, and concepts contained in the meta discipline of science in a learning that is expected to improve abilities both in the cognitive, affective and psychomotor aspects of students in the face of technological progress. This research discusses how the implementation of STEAM in 21st Century learning, specifically science learning. This study aims to provide benefits related to STEAM (Science, Technology, Engineering, Arts and Mathematics and its Implemenlation in the 21st Century learning, especially science learning in schools, both teachers and lecturers as instructors.
\end{abstract}

Keywords: Implementation, STEAM, 21st Century Learning. 


\section{PENDAHULUAN}

Tuntutan Kerja Abad 21 menghendaki pekerja untuk memiliki berbagai keterampilan terkait seperti berpikir kreatif, pemecahan masalah dan berkomunikasi. Hal ini sebagaimana dinyatakan oleh National Education Association (2012) bahwa jika siswa ingin bersaing di era global maka mereka harus memiliki kemampuan

(Communication), berkomunikasi berkolaborasi

(Colaboration), berpikir kritis (Critical thinking) dan kreativitas (Creativity) atau dikenal dengan 4C.

Menurut Bybee, (2010) jika siswa hanya belajar untuk mengingat dan melafalkan kembali pengetahuan dan mempraktikan keahlian tertentu (pembelajaran tradisional, chalk and talk teaching) dikhawatirkan mereka hanya disiapkan untuk satu jenis pekerjaan saja yang kenyataannya keahliankeahlian tertentu tersebut mulai kurang menjual di dunia kerja saat ini.

Dalam kenyataannya proses pembelajaran yang dilakukan guru di indonesia belum mengarahkan siswanya untuk mampu berpikir tingkat tinggi yang merupakan tuntutan kerja abad 21 sebagaimana tercermin dari hasil PISA tahun 2015 dimana indonesia berada pada urutan 63 dari 72 negara yang di survey. Hal ini tentunya tangtangan bagi Guru IPA untuk melakukan proses pembelajaran yang dapat merangsang siswa untuk mengembangkan kemampuan siswa dibidang sains dan matematika.

Masalah yang dihadapi oleh siswa di sekolah adalah menghubungkan antara satu materi dengan materi yang lain, bahkan yang lebih sulit adalah menghubungkan antar bidang studi, untuk mengatasi masalah tersebut maka perlu dicari pendekatan yang dapat mengintegrasikan antar bidang studi secara nyata dan siswa merasakan ada tidaknya keterkaitan dan manfaatnya dalam pembelajaran yang kontekstual. Salah satu upaya dalam mengintegrasikan antar bidang studi dalam pembelajaran IPA di sekolah adalah dengan menggunakan pembelajaran STEAM (Science, Technology, Engineeering, Art and Mathematic).

Pembelajaran Abad 21 merupakan pembelajaran yang mempersiapkan generasi abad 21. Ada tiga subjek utama dalam pembelajaran abad 21 yaitu (1) keterampialn belajar dan berinovasi yang meliputi cara berpikir dan bekerja. (2). informasi, media dan teknologi yang meliputi alat-alat yang digunakan dalam bekerja. (3). keterampilan hidup dan berkarir yang meliputi keterampilan hidup di dunia. Cara berpikir yaitu keterampilan berpikir yang harus dikuasai siswa untuk menghadapi abad 21, kemampuan berpikir tersebut diantaranya berpikir kreatif, berpikir kritis, pemecahan masalah dan pengambilan keputusan. Sedangkan cara bekerja yaitu kemampuan untuk bekerja di dunia global dan digital, siswa harus mampu berkomunikasi, bekerja sama dan berkolaborasi baik dengan individu maupun dengan kominitas dan jaringan, siswa juga harus mampu menguasai alat untuk bekerja.

Pembelajaran abad 21 hendaknya relevan dengan tantangan dan tuntutan kehidupan nyata, antara lain memunculkan kemampuan bekerja sama, kemampuan memecahkan masalah, kemampuan untuk menguasai diri, kemampuan berpikir kritis, menguasai teknologi, dan mampu mengolah informasi serta berkomunikasi dengan efektif. Hal ini sesuai dengan Undang-Undang No 20 Tahun 2003 tentang tujuan pendidikan nasional mengembangkan kemampuan dan membentuk watak serta peradaban bangsa yang bermartabat dalam rangka mencerdaskan kehidupan bangsa. Dalam proses pelaksanaan pembelajaran hendaknya mampu mendorong diri siswa sebagai pribadi dan warga negara yang beriman, produktif, kreatif, inovatif serta mampu berkontribusi pada kehidupan bermasyarakat, berbangsa dan bernegara dan peradaban dunia.

STEAM (Science, Technology, Engineering, Art and Mathematic) adalah sebuah pendekatan pembelajaran yang memberikan siswa kesempatan untuk memperluas pengetahuan dan sains dan humaniora dan pada saat yang sama 
mengembangkan keterampilan untuk berkembang pada abad ke 21 ini seperti keterampilan komunikasi, kemampuan berpikir kritis, kepemimpinan, kerja tim, kreativitas, ketangguhan dan keterampilan lainnya.

Menurut Zubaidah (2019), STEAM (Science, Technology, Engineering, Art and Mathematic) memberdayakan guru untuk pembelajaran berbasis proyek yang melibatkan lima disiplin ilmu (sains, teknologi, rekayasa, seni dan matematika) dan menumbuhkan lingkungan belajar yang inklusif dimana semua siswa yang terlibat berkontribusi. Berbeda dengan model pembelajaran tradisional, pendidik yang menggunakan kerangka STEAM, menyatukan disiplin ilmu, meningkatkan sinergi dinamis antara proses sekaligus melaui pendekatan holistik tersebut. Bahkan bagi siswa yang tidak memiliki karir di salah satu bidang STEM atau STEAM, keterampilan siswa yang diperoleh dari pembelajaran STEAM dapat di transmisikan ke dalam hampir semua karir kedepan.

Dalam kajian literatur ini penulis akan mencoba memaparkan tentang STEAM (Science, Technology, Engineering, Art and Mathematic) Dalam Pembelajaran Abad 21.

\section{METODE}

Metode yang digunakan dalam penelitian ini adalah metode telaah pustaka. Metode telaah pustaka adalah kajian kritis atas pembahasan suatu topik yang sudah ditulis oleh para peneliti atau ilmuan di dalam berbagai sumber. Sumber informasi dapat berupa buku, jurnal, ebook, ataupun artikel ilmiah lainnya. Adapun langkah-langkah penulisan yang dilakukan adalah: a). Pengumpulan data mengenai STEAM (Science,, Technology, Engineering, Art and Mathematic) dan implementasinya dalam pembelajaran abad 21 b). menganalisis data yang diperoleh berdasarkan pemikiran penulis; dan c) menyimpulkan hasil telaah pustaka.

\section{HASIL DAN PEMBAHASAN}

\section{Perubahan STEM kepada STEAM}

Satu bidang yang telah mendapat perhatian dalam perdebatan pendidikan global kini adalah perubahan STEM kepada STEAM, dorongan yang memasukkan kesenian $($ Arts $)+($ STEM $)=$ (STEAM) kepada pembelajaran sains, teknologi, kejuruteraan dan matematik (Maeda, 2013). Kemunculan gerakan STEM kepada STEAM berasaskan kepada sebuah usaha untuk melibatkan kesenian ke dalam STEM sebagai suatu aspek yang sama penting dan bukan sekadar subjek tambahan (Bequette, 2011). Pendidikan STEAM berdasarkan kepada premis bahwa STEM dan kesenian berfungsi lebih berkesan bila digabung sesama sendiri berbanding jika digunakan secara tunggal. STEAM merupakan tema baru, tapi kerja sama antara seni dan STEM bukan ide baru. Eisner dan Powell (2002) juga menjabarkan pandangan seni dan sains berada di dunia yang berbeda, dan menekankan persamaan yang dapat dilihat merentas pelbagai disiplin. Gerakan STEM ke STEAM memberikan sebuah bahasa baru untuk membentuk pemikiran merentas disiplin.

\section{Apa itu STEAM?}

Penulis mengawali melakukan penelitian dengan mengimplementasikan pembelajaran IPA berbasis STEM berbantuan ICT pada tahun 2019 dan ternyata mampu meningkatkan pembelajaran IPA di sekolah. pada Kesempatan kali ini Penulis ingin memaparkan mengenai implementasi STEAM dalam pembelajaran Abad 21.

STEAM (Science, Technology, Engineering, Art and Mathematic) merupakan pengembangan dari pendidikan STEM dengan menambahkan unsur seni (Art) dalam kegiatan pembelajarannya.

STEAM menstimulasi keingintahuan dan motivasi siswa mengenai keterampilan berpikir tingkat tinggi yang meliputi pemecahan masalah, kerja sama, pembelajaran mandiri, pembelajaran berbasis proyek, pembelajaran berbasis 
tantangan dan penelitian. Kegiatan pembelajaran yang sesuai dengan pendekatan STEAM yaitu pembelajaran berbasis proyek (Project Based Learning). Pengunaan Project Based Learning, bertitik tolak pada anggapan bahwa pemecahan masalah tidak akan tuntas jika tidak ditinjau dari berbagai segi (Mentari, 208:43).

STEAM menggabungkan "arts" (seni) dengan pembelajaran STEM untuk tujuan meningkatkan keterlibatan siswa , kreativitas, inovasi, keterampilan pemecahan masalah dan manfaat kognitif lainnya (Liao, 2016), dan untuk meningkatkan keterampilan kerja (misalnya kerja tim, komunikasi, kemampuan beradaptasi) yang diperlukan untuk karier dan kemajuan ekonomi (Colluci-Grey et al 2017)

$$
\text { Yakman (Tritiyatma, 207:5) }
$$

pembelajaran dengan pendekatan STEAM merupakan pembelajaran Kontekstual dimana siswa akan diajak memahami fenomena-fenomena yang terjadi yang dekat dengan dirinya. Pendekatan STEAM mendorong siswa untuk belajar mengeksplorasi semua kemampuan yang dimilikinya dengan cara masing-masing. STEAM juga akan memunculkan karya yang berbeda dari setiap individu atau kelompoknya. Selain itu, kolaborasi, kerja sama dan komunikasi akan muncul dalam proses pembelajaran karena pendekatan ini dilakukan secara berkelompok. Pengelompokkan siswa dalam STEAM menuntut tanggung jawab secara personal atau interpersonal terhadap pembelajaran yang terjadi. Proses ini akan membangun pemahaman siswa terhadap materi yang sedang dipelajari.

STEAM bisa didefinisikan sebagai suatu pendekatan pemgajaran dan pembelajaran antara dua atau lebih komponen atau antara satu komponen STEAM dengan disiplin ilmu lain. Istilah STEAM (Science, Technology, Engineering, Art and Mathematic), pengintegrasian seni dengan disiplin ilmu lain sebenarnya telah lama dilakukan, seni dianggap sebagai penyeimbang ilmu pengetahuan, bahkan plato pernah menuliskan "The object of education is to teach us love of beauty"(Grube, 1974), objek dari pendidikan adalah untuk mengajarkan kita mencintai keindahan. Penintegrasian seni dalam STEAM diharapkan mampu membuat pembelajaran lebih bermakna, karena siswa ikut terlibat dalam mewujudkan kompetensi pembelajaran yang harus dicapainya secara nyata dalam bentuk karya.

Menurut Gigliotti (1998), yang perspektifnya dibentuk oleh karir sebagai seorang profesor seni dan desain, pendidikan berarti"memberikan sesuatu lingkungan dimana siswa merasa benarbenar terdorong untuk terlibat dalam penciptaan masa depan mereka dengan memahami betapa pentingnya kehadiran mereka". Hal ini membutuhkan guru yang "berharap siswa dapat menyumbangkan sesuatu yang penting dan unik untuk sebuah proyek".

Cunningham (2014) mengeksplorasi paksaan ini dalam hal seni bagaimana partisipatif dapat mendodrong keterlibatan masyarakat dan memperluas kapasitas untuk imajinasi: kita perlu warga negara yang bisa membayangkan sebuah dunia yang berbeda. Menurut Guy A. Boy dan Yakman, STEAM (Science, Technology, Engineering, Arts and mathematics) merupakan pendekatan yang terintegrasi untuk dapat mendorong kreativitas. Meningkatkan unsur-unsur pada STEAM dalam pembelajaran dapat mendorong siswa untuk mencari keterkaitan dari satu dengan yang lain. Masuknya unsur seni pada STEAM akan dapat mengembangkan kemampuan siswa secara estetik.

Buinicontro (2017) Mendefinisikan STEAM sebagai integrasi displin ilmu seni ke dalam kurikulum dan pembelajaran pada wilayah sains, teknologi, teknik dan matematik (STEM). Unsur seni yang tentunya akan memberikan pengaruh positif bagi siapa saja yang menikmatinya. Integrasi unsur seni dalam STEAM dapat memberikan kesempatan kepada peserta didik untuk berkreasi dan berinovasi dalam bentuk kreativitas seni yang dipadukan 
dalam outcome pembelajaran. Produk STEAM tidak hanya memuat beberapa aspek kognitif, namun akan membuat beberapa aspek lain yaitu afektif dan psikomotor yang dapat dikembangkan secara general oleh peserta didik dalam menghadapi era revolusi industri 4.0. Kompleksitas abad 21 dewasa ini menuntut kemampuan dari berbagai bidang dan pembelajaran berbasis STEAM dapat menjadi persiapan dan latihan menghadapi semuanya (Wijaya dkk, 2015). Oleh karena itu, kemampuan kognitif dan kreativitas harus terus dikembangkan dalam berbagai bentuk salah satunya melalui pembelajaran berbasis STEAM yang mengintegrasikan desain, kreativitas, inovasi, teknik dan matematika sehingga dapat mengembangkan kemampuankemampuan yang dibutuhkan dalam menghadapi globalisasi dan perkembangan ilmu pengetahuan dan teknologi.

\section{Implementasi STEAM (Science, Technology, Engineering, Arts and Mathematics) dalam Pembelajaran Abad 21}

Pembelajaran dengan pendekatan STEAM merupakan pembelajaran kontekstual (Yakman,2013), dimana siswa akan diajak memahami fenomenafenomena yang terjadi yang dekat dengan dirinya. Dengan pembelajaran seperti ini, siswa akan merasa ingin lebih tahu, ingin belajar dan memahami apa yang sedang terjadi, penyebab-penyebabnya, dan dampak yang ditimbulkan serta berusaha untuk mengatasinya. Hal ini terjadi karena siswa dapat langsung mengaitkan, menghubungkan dan bahkan bisa mencari solusi pada permasalahaan yang muncul, dalam model pembelajaran ini siswa diajar berpikir kritis. Pendekatan STEAM mendorong siswa untuk belajar mengeskplorasi semua kemampuan yang dimilikinya dengan cara masing-masing. STEAM juga akan memunculkan karya yang berbeda dan tidak terduga dari setiap individu, atau kelompoknya. Selain itu, kolaborasi, kerja sama, dan komunikasi akan muncul dalam proses pembelajaran karena pendekatan ini dilakukan secara berkelompok. Pengelompokkan siswa dalam STEAM menuntut tanggung jawab secara personal maupun interpersonal terhadap pembelajaran yang terjadi, proses ini akan membangun pemahaman siswa terhadap materi yang sedang dipelajari. Secara aktif siswa kan menciptakan strategi secara mandiri untuk proses belajarnya. Pendekatan STEAM ini mengarahkan siswa untuk memiliki keterampilan yaitu keterampilan pemecahan masalah keterampilan berpikir kritis, dan keterampilan kolaborasi (Messier, 2015).

Pendekatan STEAM mengupayakan siswa untuk membangun pemahamannya sendiri dari proses pembelajaran dengan mengintegrasikan beberapa bidang studi dalam kehidupan nyata. STEAM juga mengeksplorasi kemampuan siswa dengan menggunakan teknologi yang terkait, yang dapat dipilih oleh siswa atau yang digemari dan dikomunikasikan dengan cara yang menarik seperti seni. Pemahaman pada pembelajaran dengan STEAM juga dapat diperoleh siswa melalui kerja kelompok dengan inkuiri (Susan Balckley and Rachel Sheffield). Dalam hal ini, siswa belajar mencari dan menemukan konsep yang sedang dipelajari secara mandiri, baik secara individu maupun kelompok.

Pembelajaran berbasis STEAM yang dibutuhkan oleh siswa-siswi di indonesia sebagai upaya untuk melatih kemampuan dan bakat mereka menghadapi masalah abad 21. kompleksitas abad 21 dewasa ini menuntut kemampuan dari berbagai bidang dan pembelajaran yang berbasis STEAM dapat menjadi persiapan dan latihan menghadapi semuanya. Desain, kreativitas, dan inovasi merupakan unsur art yang dipadukan yang pada awalnya STEM (Science, Technology,Engieering, and Mathematics ) menjadi STEAM (penambahan unsur $A r t$ ).

Berbagai upaya telah dilakukan oleh pemerintah dalam menyongsong pendidikan abad 21. Salah satu upaya tersebut adalah dengan melakukan perubahan kurikulum nasional menjadi 
kurikulum 2013 (K13) yang berbasis pada pembelajaran abad 21.

Pembelajaran abad 21 adalah pembelajaran yang mempersiapkan generasi abad 21 dengan tiga subjek utama dalam pembelajaran yaitu (1) keterampilan belajar dan berinovasi. (2) informasi, media, dan teknologi, dan (3) keterampilan hidup dan berkarir. Keterampilan berpikir yang harus dikuasai oleh peserta didik dalam pendidikan pada abad 21 adalah berpikir kreatif, kritis,pemecahan masalah. dan pengambilan keputusan. Cara bekerja atau kemampuan untuk bekerja pada dunia global dan digital adalah peserta didik harus mampu berkomunikasi dan berkolaborasi, baik dengan individu maupun komunitas dan jaringan. Peserta didik juga harus dapat menguasai alat dan teknologi untuk bekerja.

Pada kurikulum 2013 yang mana pembelajarannya diimplementasikan secara tematik terintegrasi cocok untuk memadukan pembelajaran berbasis STEAM. Sekolah dasar dan menengah pertama adalah tingkatan satuan pendidikan yang cocok untuk penerapannya yang mana untuk sekolah dasar mata pelajaran IPS dan IPA telah dipadukan umtuk menunjang pembelajaran berbasis STEAM.

Pada tingkat satuan sekolah menengah pertama mata pelajaran IPA dan IPS telah dipadukam maka pada keduanya pembelajaran berbasis STEAM dapat diimplementasikan. Output yang diinginkan seharusnya bisa lebih kompleks dari output sekolah dasar. Pada mata pelajaran IPA maka produk maupun desain yang dpaat dikembangkan seperti pembangkit listrik mikro hidro, rangkaian listrik sederhana, dan media-media lainnya. Pemanfaatan materi-materi yang dilingkungan para siswa dalam hal ini dapat digunakan.

STEAM adalah sebuah pendekatan pembelajaran interdisiplin yang memadukan antara pengetahuan (science), teknologi (technology, teknik (engineering), seni (arts) dan matematika (mathematics). Kelima disiplin ilmu tersebut menjsdi salah satu pendekatan pendidikan yang secara komprehensip sebagai pola pemecahan masalah melalui pengalaman belajar abad 21 .

STEAM merupakan salah satu pembelajaran kooperatif sebagai bagian dari pembelajaran konstruktivisme, dimana peseta didik akan membangun pengetahuan dan pemahamannya sendiri melalui proyek. Proyek yang diberikan tersebut menuntut peserta didik untuk memahami materi yang sedang dipelajari sebagai sebuah pengetahuan, memanfaatkan teknologi, yang sedang berkembang untuk membantu menemukan konsep. Kemudian hasilnya disajikan dengan memperhatikan etika dan estetika sebagai seni, serta menampilkan bentukbentuk materi dengan manifestasi matematika.

\section{Tahapan Implementasi Pembelajaran STEAM}

STEAM merupakan salah satu pembelajaran kooperatif sebagai bagian dari pembelajaran kontruktivisme, dimana peserta didik akan membangun pengetahuan dan pemahamannya sendiri melalui proyek. Proyek yang diberikan tersebut menuntut peserta didik untuk memahami materi yang sedang dipelajari sebagai sebuah pengetahuan, memanfaatkan teknologi yang sedang berkembang untuk membantu menemukan konsep. Setiap tahapan STEAM yang terintegrasi pembelajaran berbasis proyek diharapkan dapat memunculkan keterampilan abad 21.

Secara umum STEAM yang terintegrasi dengan pembelajaran berbasis proyek, menempuh enam tahap, sebagai berikut.

a. Pemberian Pertanyaan esensial pertanyaan esensial digunakan untuk memberikan gambaran tentang pengetahuan awal yang dimiliki peserta didik.

\section{b. Penyusunan Rencana Proyek}

Peserta didik mendiskusikan secara berkelompok tentang rancangan tahapan penyelesaian proyek , mencari informasi mengenai penyelesaian dan 
kendala yang dihadapi dalam pelaksanaan proyek, waktu maksimal yang diperlukan dalam penyelesaian proyek dan desain proyek yang akan dikerjakan dengan mengintegrasikan komponen STEAM.

\section{c. Penyusunan Jadwal}

Peserta didik mampu menyelesaikan proyek dengan waktu yang telah disepakati. Mereka dapat mendikusikan jadwal ini bersama kelompoknya.

\section{d. Monitoring kemajuan Proyek}

Guru harus melihat kesesuaian waktu saat penyelesaian proyek . Monitoring aktivitas peserta didik selama proses pembelajaran dan melihat perkembangan proyek dilakukan untuk mengetahui sejauh mana mereka dapat menyelesaikan proyek yang telah ditetapkan sesuai dengan timeline yang telah dibuat.

\section{e. Pengujian dan Penilaian Hasil}

Tahapan ini dilakukan dengan cara guru menguji dan mengevaluasi produk yang dihasilkan oleh peserta didik.

\section{f. Evaluasi Pengalaman}

Tahap evaluasi Pengalaman dilakukan oleh peserta didik dengan mengungkapkan perasaan dan pengalamannya selama menyelesaikan pembelajaran berbasis proyek. Guru dan peserta didik melakukan refleksi trhadap aktivitas pembelajaran dan hasil proyek yang telah dilaksanakan.

\section{Aktivitas STEAM pada Pelajaran IPA di kelas}

Pembelajaran menggunakan STEAM dalam Pembelajaran Abad 21 khususnya pada pelajaran IPA secara langsung memberikan pengalaman pada peserta didik tentang:

a. Sains (Science)

Pembelajaran sains di sekolah untuk peserta didik memfokuskan pada pembelajaran mengenai diri sendiri,alam sekitar dan gejala-gejala alam. Manfaat pembelajaran sains pada peserta didik untuk :

1) belajar melakukan explorasi dan investigasi, yaitu kegiatan untuk mengamati dan menyelidiki objek serta fenomena alam.

2) belajar mengembangkan keterampilan proses sains dasar, seperti melakukan pengamatan, mengukur, mengkomunikasikan hasil pengamatan, dsb;

3) belajar mengembangkan rasa ingin tahu, rasa senang dan mau melakukan inkuiri atau penemuan;

4) belajar memahami pengetahuan tentang berbagai benda baik ciri, struktur maupun fungsinya. Beberapa permainan atau percobaan sains yang dilakukan di sekolah antara lain: percobaan gunung meletus, percobaan kapuk melapuk, percobaan air mancur cola, percobaan busa, percobaan telur mengambang, percobaan mengambang tanpa meniuo, percobaan kapur barus terapung dan percobaan jagung menari.

b. Teknologi (Technology)

Dalam pembelajaran abad 21 khususnya pada pelajaran IPA, istilah teknologi mengacu pada penggunaan peralatan dan mengembangkan motoric kasar dan motorik halus. Peralatan atau perkakas dapat membantu peserta didik untuk mengembangkan koordinasi tangan dan mata, serta melatih dan menguatkan otot tangan dan jari untuk menulis, mengetik dan menggambar. Contoh permainan teknologi untuk peserta didik anatara lain:

1) bermain game educatif

2)bermain dengan teknologi non elektronik seperti: gunting, pipet, gelas ukur, main pembangunan, balok set, lego, timbangan paperclips, peralatan tulis, tabung bekas tisu gulung, sedotan plastik, papan kayu,penggaris, pelubang kertas, boto spray, stapler.

c. Teknik (Engineering)

Engineering (teknik) adalah pengetahuan untuk mengoperasikan atau mendesain sebuah masalah. Atau dapat dikatakan engineering adalah 
keterampilan yang dimiliki seseorang untuk mengoperasikan atau merangkai sesuatu. Kemampuan engineering untuk peserta didik meliputi kemampuan merangkai atau membangun suatu bentuk menggunakan berbagai media.

d. Seni (Art)

Kemampuan seni pada peserta didik meliputi mengenal dan menunjukkan berbagai karya dan aktivitas seni, seperti menggambar, melukis, dengan jari, mencap, melipat, bermain musik, ekspresi gerak sesuai irama, mendesain sebuah hasil karya, seni pertunjukan seperti mini drama, bernyanyi, bercerita, dan eksplorasi dengan benda-benda yang dapat digunakan untuk menghasilkan karya seni.

e. Matematika (Mathematics)

Permainan matematika yang dapat dimainkan oleh peserta didik antara lain:

1) Bermain ukuran dan warna

2) permainan memilah bentuk

3) Permainan mengenal pola

4) Perhitungan kalori tubuh manusia dsb.

Implementasi STEAM dalam pembelajaran abad 21 sangat berguna dan bermanfaat, dapat diketahui bahwa tidak hanya aspek kognitif yang kembangkan, pembelajaran STEAM juga dapat mengembangkan kemampuan skill peserta didik untuk menghadapi tantangan era globalisasi dimasa mendatang.

\section{KESIMPULAN}

Implementasi STEAM dalam pembelajaran abad 21 dapat melatih kemampuan dan bakat siswa meghadapi masalah abad 21. Selain itu pembelajaran di sekolah yang berdasarkan Tema yang berbasis STEAM diharapkan dapat menghasilkan luaran akhir (output) berupa produk maupun desain yang dibuat para siswa yang berhubungan dengan desain. Sedangkan pada tingkat satuan sekolah menengah pertama pada mata pelajaran IPA telah dipadukan maka pada keduanya pembelajaran STEAM dapat diimplementasikan sehingga Output yang diinginkan seharusnya bisa lebih kompleks dari output sekolah dasar.

\section{DAFTAR PUSTAKA}

Aristantia, Gina.(2017). Penerapan Science Technologu Engineering, Art Mathematics Pada Tema Air dan Kita Untuk Meningkatkan Penguasaan Konsep dan Mengetahui Profil Karakter Peserta Didik SMP. Skripsi UPI: Tidak ditebitkan

Az Zahra, Balgis. (2017). Pengaruh pembelajaran Berbasis STEAM Terhadap Kreativitas dan Penguasaan Kognitif Siswa pada Konsep Bunyi. Skripsi UPI: Tidak diterbitkan.

Bahrum, Suraya., Md Nasir Ibrahim, et al. (2018). "Kebolehgunaan Modul STEAM dalam Pengajaran dan Pembelajaran Pendidikan Seni Visual Sekolah Rendah". KUPAS SENI Jurnal Seni dan Pendidikan Seni. Vol. 6(2018)/ (65-79).

Bybee,R.(2010). "What is STEM education?".Journal Science Vol. 329p 996

Colucci-Gray, L., Trowsdalle, J., Cooke, C. F., Davies, R., Burnard, P., \& Gray, D. S. (2017).

Reviewing the potential and challenges of developing STEAM education through creative pedagogies for 21st learning: How can school curricula be broadened towards a more responsive, dynamic, and inclusive form of education? British Educational Research Association.

Gates, A. E. (2017). Bnenefits of a STEAM collaboration in Nemark, New Jersey: Volcano 
simulation through a glass-making experinece. Journal of Geoscience Education. 65(1), 4-11.

Liao,C.(2016). From interdisciplinary to transdisciplinary: An arts-integrated Aproach to STEAM education. Art Education, 69(6),44-49.

Limbong, Irmayani, Muniroh munawar, et al.(2019). Perencanaan pembelajaran Berbasis STEAM (Science, Technology, Engineering, Art, Mathematics). Seminar Nasional PAUD, 203-212.

Munawar,Muniroh, Fenny Rushayanti, et al.(2019). Implemetation of STEAM (Science, Technologi, Engineering, Art and Mathematics)-Based Erarly Chilhood Education Leraning in Semarang City. Journal.Ceria. Vol.2 No.5.

National Education Association, (2012). "Preparing 21st Century Students For A Global Society".

Nurhikmayati, Iik.(2019). Implementasi STEAM Dalam Pembelajaran Matematika. Jurnal Didactical Mathematics. Vol.1 No.2 April 2019 hal 41-50.

Quigley, C. F., Herro, D., \& Jamil F.M (2017). Developing a conceptual model of STEAM teaching practices. School Science and Mathematics, 117(1-2), 1-12.

Rika anisa, M. Haris Effendi Hsb, et al.,(2019). Peningkatan Kemampuan Berpikir Kreatif Siswa dengan Menggunakan Model Project Based Learning Berbasis STEAM (Science, Technology, Engineering, Art and Mathematics) Pada Materi Asam
Basa di SMAN 11 Kota Jambi. Tesis. Universitas Jambi: Tidak diterbitkan.

Riyanto, Agus.(2020). Penerapan Model Pembelajaran STEAM Dalam Pendidikan Abad 21.[Online] https://www.amongguru.com/penerap an-model-pembelajaran-steamdalam-pendidikan-abad-21/. Diakses tanggal 20 april 2020.

Taylor, P.C. 2016) .Why is a STEAM curriculum perspective crucial to the 21 st century? Research Conference 2016.89-93

Wijaya, Agusta Danang, Nila Karmila, et al.(2015). Implementasi Pembelajaran Berbasis STEAM (Science, Technology, Engineering, Art, Mathematics) Pada Kurikulum Indonesia. Proseding Seminar Nasional Fisikan dan Aplikasinya, Balai Sawala Unpad Padjajaran.

Yakman, Georgette., Hyongyong, Lee. (2012). Exploring The Exemplary STEAM Education in the U.S as Practical Educational Framwork for Korea. J Korea Assoc. Sci. Edu. Vol 32, No.6, 2012. (Diakses 20 April 2020)

Zubaidah, S. (2019). STEAM (Science, Technology Engineering, Art and Mathematics): Pembelajaran Untuk Memberdayakan Keterampilan Abad Ke-21. Seminar Nasional Matematika dan Sains dengan Tema "STEAM Terintegrasi Kearifan Lokal Dalam Menghadapi Era Revolusi Industri 4.0" di FKIP Universitas Wiralodra Indramayu 19 September 2019. 